\title{
The Use of Critical Reading in Understanding Scientific Texts on Academic Performance and Problem-solving Skills
}

\author{
Özlem Koray ${ }^{1 *}$, Sercan Çetinklıç \\ ${ }^{1}$ Department of Mathematics and Science Education, Ereğli Education Faculty, Zonguldak Bulent Ecevit University, Kdz. Ereğli, Zonguldak, \\ ${ }^{2} 15$ Temmuz Şehitleri İmam Hatip Secondary School, Kdz. Ereğli, Zonguldak
}

*Corresponding Author: ocankoray@gmail.com

\section{ABSTRACT}

This study aimed to investigate the effect of critical reading (CR) practices in science courses on academic achievement, science performance level, and problem-solving skills. The experimental method and factorial design were used. The study was conducted with 102 seventh-grade students from a public school in Turkey during the 2014-2015 academic year. Experimental and control groups were formed. CR practices were followed in the experimental group and teaching practices appropriate to the curriculum were used in the control group. Data were collected with the "Multiple-Choice Academic Achievement Test" to determine the students' academic level in the "Human and Environment Unit: The Science Performance Level Test" to determine their science performance level and the "Logical Thinking Group Test" to determine the level of their problem-solving skills. The variables of academic achievement and science performance levels were labeled "Academic Performance." Independent samples two-way ANOVA was applied to analyze the data using SPSS 18.0 software. The results revealed that the students in the experimental group, who were taught science using CR practices, were significantly more successful than the students in the control group, whose teaching was appropriate to the current curriculum in terms of academic achievement, science performance level, and problem-solving skills. It is of critical importance to use such innovative practices, which combine various disciplines, to allow students to excel at reading, which is a basic skill, at all educational levels in order to raise contemporary and social individuals.

KEY WORDS: critical reading; critical thinking; science teaching; scientific text

\section{INTRODUCTION}

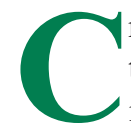

ritical thinking, one of the most important concepts of the $21^{\text {st }}$ century, involves analyzing concepts, generating ideas and organizing them, defending perspectives, making comparisons, making inferences, evaluating discussions, and problem-solving skills (Browne and Keeley, 2007; Pithers and Soden, 2000). To engage in critical reading (CR), according to a different definition, is to read bearing in mind that there may be alternative explanations, rather than making a conclusion based on the information read (Akın et al., 2015). Paul (1992) defined critical thinking as reaching a conclusion based on observation and information. Critical thinking is related to the high-level thinking skills requiring analysis, synthesis, and evaluation, rather than low-level thinking skills associated with knowledge, comprehension, and application in Bloom's taxonomy (Cottrell, 2011; Dam and Volman, 2004; Ennis, 1985). Although critical thinking is not the basic aim of education, it is closely related to what is taught and learned in a teaching environment. It has a field of interest covering the curriculum's purposes, textbooks, assessment, and personal development. The most important condition for developing critical thinking in individuals from a young age is to provide learning environments where they can express and discuss their ideas, question information, and produce more than one alternative interpretation in real life. This is because students' thinking skills are not expected to develop unless they are offered something on which they can think; in other words, unless they are occupied with meaningful and rich lessons (Brown, 1997). To provide an education in which students learn how to think and produce effective solutions to problems, it is necessary to consider critical thinking as a skill and to adopt an interdisciplinary approach. In addition, one of the topics given significant emphasis in many areas of reform in education and areas requiring reform is highlevel thinking skills (Halpern, 1998). Critical thinking is one of the high level skills. It is thought that research on how to develop critical thinking skills in individuals would contribute to reform movements in education.

\section{CR}

Reading, a basic language skill, has a significant place in the individual's intellectual life because of perception, sensemaking, acquisition of knowledge, and reusing acquired knowledge in communicative processes largely depend on reading effectiveness. The most important goal of a reading process is the development of CR skills (Flynn, 1989). The concept of CR, a critical thinking skill, has recently been suggested as a model of understanding, particularly in education, to shed light on the complex process that is 
characterized as "reading." CR does not refer to careful and detailed reading (Yu, 2015). It is defined as thinking about the text being read, speculating about the truths and faults of the text, and interpreting its content (Aşılığlu, 2008). In other words, CR is arriving at a judgment using the reader's mind (Özdemir, 2007). Literacy Gains (2009) defined CR as an attitude, an emotional and intellectual behavior, a mental stance that the reader reveals while reading a text. CR is the science and art of examining and evaluating a text and adopting a perspective, according to Paul and Elder (2008). Characterizing CR as "ideal reading," Arıc1 (2008) indicated that it is the ability to enter a communicative interaction with the text and to make interpretations and evaluations regarding it. Altunsöz (2016) defined CR as reading by asking questions regarding the conflicts, consistencies, and inconsistencies in the thoughts or expressions in the text and the reasons why it was written. Four basic elements of CR are: Determining the author's perspective, detecting primary claims and the main idea, determining supportive details used to strengthen thoughts, and evaluating supportive details (Maker and Lenier, 1996). Emiroğlu (2014) compiled the following CR skills from various studies: determining the aim to read the text, analyzing the reliability of the text, comparing prior knowledge with what the text says, comparing the information given in the text with other sources, understanding what is said implicitly, understanding the purpose of the author, understanding the target audience of the author, determining the perspective of the author, distinguishing perspectives from realities, making predictions based on particular parts of the texts, determining the type of the text, determining characteristics of the author's language, determining the main idea, evaluating the text by asking questions, making inferences, and summarizing the text in one's own words.

Being a critical reader requires making reliable observations, making inferences, and establishing rational hypotheses. In addition, the ability to keep what is read in mind can be achieved through CR (Norris, 1985). Critical readers are curious about the author's reasons for writing the text, the meaning, and prolificacy of the text, they know that everyone can make mistakes, including the writers of textbooks, and try various interpretations without ignoring their interpretations, and examine written materials as a whole (Paul et al., 1990). According to McLaughlin and De Voogd (2004a), critical literacy improves the logical thinking of teachers and students, teaches them to approach situations from different points of view, and produces active thinkers. CR requires thinking beyond the text; that is to say, it requires one to understand why the author wrote about a particular subject and from a particular perspective, and why the author included and excluded certain ideas (McLaughlin and De Voogd, 2004b). According to Molden (2007), a thorough examination of the text is conducted using analytic skills; therefore, all pieces of the text are reviewed. Critical readers establish a balance between themselves and the author, move beyond what is written by approaching the text from all angles, and actively use the insights obtained by determining the purpose and perspective of the author. Critical readers, thus, develop an independent perspective. In conclusion, $\mathrm{CR}$ addressees beyond the text and reading with the same discipline and requires control over the text.

\section{LITERATURE REVIEW}

A literature review revealed many findings on $\mathrm{CR}$. McClune and Jarman (2010) created a panel with 26 experts in the field of reading critically scientific newspaper texts in terms of developing knowledge, skill, and attitude, who brought attention to certain points and made recommendations. They noted that the main goal of the media is not to educate but to seek economic gain and to entertain and persuade readers. For this reason, critical readers should be wary of newspaper texts.

There are a number of studies in the current programs regarding the CR of scientific texts; but, they need to be considered with an interdisciplinary approach. In addition, improving CR skills is dependent on the successful integration of different areas of the curriculum. In a study conducted with senior classes, Krug (2010) found that there is a direct relationship between teachers' experiences and applications that students learn to question texts using critical literacy approaches, criticize social injustice, engage in social acts, and finally that every student can learn how to read critically. Çam (2006) found a significant relationship between primary school fifth-grade students' visual reading level and their reading comprehension, CR, and academic achievement in Turkish classes. Students' academic achievement improves as their CR level improves. Ünal (2006) found a high-level relationship between fifth-grade students' attitudes toward reading and their CR skills and a mid-level relationship between their reading comprehension and CR skills.

A study investigating the relationship between CR and cognitive learning found that even university students' learning is limited by behaviors at the level of remembering, and memorizing what is read indicates that they do not have CR skills. Application, analysis, synthesis, and evaluation, which are among the higher steps of the cognitive domain, cannot be achieved with low-level reading (Aş1lığlu, 2008). Two different studies conducted with preservice teachers revealed that they have mid-level CR self-efficacy perception (Karabay et al., 2015) and CR skills (Maltepe, 2016). Kien and Huan (2017) sought to determine teachers' beliefs regarding CR strategies in teaching English in foreign language classrooms and quoted teachers as stating that CR strategies play a crucial role in students' understanding of reading texts. CR education programs have been seen to improve preservice teachers' metacognitive reading strategies and media literacy levels (Karabay, 2015).

As has been seen, there are many studies in the literature on CR, its relationship with various variables, and its effectiveness (Akın et al., 2015; Aşılığglu, 2008; Çam, 2006; Karabay, 2015; Kien and Huan, 2017; Krug, 2010; McClune and Jarman, 2010; Tsai et al., 
2013; Ünal, 2006). However, the most important condition for improving $\mathrm{CR}$, and thus critical thinking, are educational programs that are specialized for different disciplines and subject areas or have multidisciplinary applications. Examining the effectiveness of such programs, which are expected to have common points in terms of high-level thinking skills, is only possible with scientific studies. Further multidisciplinary experimental studies on CR can improve the quality of such programs and contribute to the dissemination of them. This study is intended to contribute to the literature by extending experimental research on CRs skills and critical thinking education in a general sense.

\section{Purpose of the Study}

This study aimed to investigate the use of $\mathrm{CR}$ practices in science courses on academic achievement, science performance level, and problem-solving skills. An interdisciplinary approach was adopted in the study and the aim was to provide a way to ease the understanding of scientific texts in science courses through developing text reading skills, which constitute the focal point of mother language teaching courses, in terms of CR.

\section{Research Questions}

Considering the scope of this study and in line with its aims, the following research questions were considered:

RQ1: Do scores on the multiple-choice academic achievement test (MCAAT) achieved by the experimental group (in which CR practices were carried out) and the control group (in which curriculum-appropriate teaching was carried out) differ according to the method implemented?

a. Do scores on the MCAAT achieved by the experimental and control groups differ according to gender?

b. Are scores on the MCAAT achieved by the experimental and control groups affected by the common effect of the method implemented and gender?

RQ2: Do scores on the science performance level test (SPLT) achieved by the experimental and control groups differ according to the method implemented?

a. Do scores on the SPLT achieved by the experimental and control groups differ according to gender?

b. Are scores on the SPLT achieved by the experimental and control groups affected by the common effect of the method implemented and gender?

RQ3: Do scores on the logical thinking group test (LTGT) achieved by the experimental and control groups differ according to the method implemented?

a. Do scores on the LTGT achieved by the experimental and control groups differ according to gender?

b. Are scores on the LTGT achieved by the experimental and control groups affected by the common effect of the method implemented and gender?

\section{METHODOLOGY}

In this section, the method and model of the study, study groups, experimental implementation, data collection tools, and statistical techniques are discussed.

\section{Method}

The semi-experimental method was used in this study. This is a method in which an artificial condition is used to detect a cause-and-effect relationship among variables to determine factors affecting findings (Çepni, 2005). When investigating the effect of independent variables on dependent variables, groups should be balanced by controlling extraneous and surprising variables in an experimental study (Sönmez and Alacapınar, 2014). This study investigated the effects of CR practices on the experimental group and gender. CR practices were used in the experimental group and teaching practices appropriate to the Ministry of National Education (MoNE) curriculum (2013) were followed in the control group. This form made the study appropriate for the factorial design. The factorial design enables the investigation of the effect of two or more variables on the dependent variable as well as the common effect of multiple independent variables on the dependent variable (Karasar, 2003). The study design is presented in Table 1.

\section{Study Groups}

The study was carried out with classes 7/A, 7/B, 7/C, and 7/D of the Black Sea Ereğli Religious Vocational High School in the Black Sea Ereğli District of Zonguldak Province, Turkey, during the 2014-2015 academic year. While determining the study group of the research, easily accessible case sampling was preferred. There were six seventh classes (three female and three male groups) in the school and four of these classes were included in the study by randomly. The classes were assigned to groups randomly: 7/C (female) was the first experimental group and 7/D (female) was the first control, 7/B (male) was the second experimental group, and 7/A (male) was the second control. Permissions for the research were obtained from institutions and parents. In addition, the students were volunteer. The statistics of each group are presented in Table 2.

The groups' equivalence was confirmed by comparison of the students' general grade point average at the end of sixth grade and their grade point average on the science and technology course at the end of the first term of seventh grade, using the Kruskal-Wallis H Test.

Four activities covering the objectives of the MoNE curriculum and $\mathrm{CR}$ on the seventh-grade human and environment unit were developed by the researchers. Before the design of the activities, the literature on $\mathrm{CR}$ was reviewed and scientific articles, periodicals, theses, and books were examined. An expert on CR was consulted in a face-to-face interview regarding the $\mathrm{CR}$ objectives and the implementation. Based on the literature review and the expert's opinion, the objectives were formed and CR practices appropriate to these objectives were designed. Four reading texts used in the activities were selected from the archive of The Scientific and Technological Researcher Council of Turkey and the journals Science Child and Science and Technique to cover the objectives of the Human and Environment unit. Five different sections lasting 


\begin{tabular}{|c|c|c|c|}
\hline \multicolumn{2}{|c|}{ Group (Factor 1) } & Gender (Factor 2) & Meas \\
\hline \multicolumn{2}{|l|}{$\mathrm{E}_{1}$} & $1^{\text {st }}$ female & $\begin{array}{l}\text { MCA } \\
\text { SPLT } \\
\text { LGG }\end{array}$ \\
\hline \multicolumn{2}{|l|}{$\mathrm{E}_{2}$} & $2^{\text {nd }}$ male & $\begin{array}{l}\text { MCA } \\
\text { SPLT } \\
\text { LGG }\end{array}$ \\
\hline \multicolumn{2}{|l|}{$\mathrm{C}_{1}$} & $1^{\text {st }}$ female & $\begin{array}{l}\text { MCA } \\
\text { SPLT } \\
\text { LGG }\end{array}$ \\
\hline \multicolumn{2}{|l|}{$\mathrm{C}_{2}$} & $2^{\text {nd }}$ male & $\begin{array}{l}\text { MCA } \\
\text { SPLT } \\
\text { LGG }\end{array}$ \\
\hline \multicolumn{4}{|c|}{$\begin{array}{l}\mathrm{E}_{1}: \text { Female experimental group taught critical reading practices, } \mathrm{E}_{2}: \text { Male } \\
\text { taught according to the MoNE curriculum, } \mathrm{C}_{2}: \text { Male control group taught a } \\
\text { practices appropriate to the MoNE curriculum, MCAAT: Multiple-choice aca } \\
\text { Science performance level test administered in the human and environment }\end{array}$} \\
\hline \multicolumn{4}{|c|}{ Table 2: Number of students in each group } \\
\hline Group & N Female & N Male & N Total \\
\hline $\mathrm{E}_{1}$ & 25 & 0 & 25 \\
\hline $\mathrm{E}_{2}$ & 0 & 24 & 24 \\
\hline $\mathrm{C}_{1}$ & 28 & 0 & 28 \\
\hline $\mathrm{C}_{2}$ & 0 & 25 & 25 \\
\hline Total & 53 & 49 & 102 \\
\hline
\end{tabular}

approximately six-lesson hours were developed for each reading text activity.

Section 1: The title of the text is given and students make predictions about the text. They are encouraged to express their thoughts. If there is an unknown word in the title, suggestions are made for students to work out its meaning.

Section 2: Various visuals are given related to the text and students are encouraged to make connections between these visuals and the text. Students are asked to imagine a visual related to the text and asked how they relate their visual and the text. Their thoughts are discussed in the classroom.

Section 3: Questions based on the students' prior knowledge and related to daily life are posed to them to enable the design of the text in students' minds and to question the purpose of reading the text. For example, students are given the script of a recent popular commercial and asked to express their thoughts on it in the activity regarding the reading text titled "How Valuable Biodiversity Is." Students are also asked to make predictions about the author of the text and to express their thoughts regarding the author. Before reading the text, students are given information about how to read it critically. Students are asked to read the text considering the following points: Making sense of words or expressions by grouping them and benefiting from the previous or next expression; finding exaggeration, humor, and conflicts in the text; determining characteristics of the text; asking themselves questions about what they are reading, engaging in the text, questioning words, sentences, and examples; underlining the important information in the text; making notes in the margins; establishing connections between visuals and the text; outlining the text; making logical inferences from the text; and questioning and evaluating the text. After reading the text, students are asked to express their thoughts about it and to share the notes they made.

Section 4: Words related to the objectives of the human and environment unit in the text are given, questions are posed, and examples are given to achieve the unit objectives. In addition, all of the relevant course objectives are taught in this section by asking relevant questions in addition to the expressions in the text. These questions take a form which encourages students to question the reliability of the information provided in the text and the author's conclusions, to distinguish expressions indicating a phenomenon and a perspective, to notice oldfashioned information, and to come to a conclusion regarding the author.

Section 5: Students are asked to evaluate the text as a whole, to identify problems in it, and to suggest how to correct these deficient points. Their conclusion regarding the text type and author is determined by their reasoning. The journal in which the text is published and the publication date is given to students and they are asked to make a comparison with their predictions.

The study was conducted by the second researcher. This researcher was a teacher of these classes normally. While the experimental group was taught according to the CR practices course plan, the control group was taught according to the annual plan of the MoNE Board of Education and Discipline. Methods of questions-and-answer, direct instruction, discussion, and demonstration were employed, using slides, videos, and interactive whiteboard applications. The implementation lasted 8 weeks, including pre-test and post-test. Pre-test and post-test were applied in a 2-week period. MCAAT, SPLT, and LTGT applications were carried 
out in a way that allows the students to answer sincerely and accurately.

\section{Data Collection Tools}

The "Multiple-Choice Academic Achievement Test" was used to determine the students' academic achievement in the human and environment unit, the "Science Performance Level Test" was used to determine their science performance level, and the "Logical Thinking Group Test" was used to determine their problem-solving levels. The variables of academic achievement and science performance level together were termed "academic performance." All data collection tools were applied to the experimental and control groups as pretest and post-test.

\section{MCAAT}

The MCAAT has 39 four-choice multiple-choice questions, the majority of which have been asked in central exams conducted by MoNE were first developed to determine the students' academic achievement level in the human and environment unit. Three science teachers with 4, 7, and 15 years' professional experience in a state school and an educational faculty professor who is an expert on the field were consulted regarding the appropriateness of the questions for the objectives and the students' level. Nine questions were considered to be inappropriate and thus excluded, leaving 30 questions. The pilot study of the test was carried out with $8^{\text {th }}$-grade students. The reliability of the 30 -question test was analyzed using the Iteman program and the alpha reliability coefficient was found to be .83. The test was applied to the experimental and control groups at pre-test and post-test and lasted approximately $40 \mathrm{~min}$. Each correct answer was awarded 1 point and each incorrect answer received 0 points. According to this grading, the maximum and minimum scores one can obtain on MCAAT are 30 and 0 points, respectively.

\section{SPLT}

The SPLT has a total of seven questions. These were developed to determine the students' science performance level. Six are open-ended and one required drawing a figure, and they were grouped under three main questions that were appropriate to the objectives of the Human and Environment Unit. Questions under the themes of "Greenhouse and Acid Rain" were taken directly from the Programme for International Student Assessment (PISA) and the questions under the themes of "Environmentalist Solutions" and "The Food Chain" were taken directly from the Trends in International Mathematics and Science Study (TIMMS). PISA is an assessment to determine 15-year-olds' science and mathematics literacy and reading skills in today's information society. TIMMS, on the other hand, is a multifaceted assessment that measures the mathematics and science achievement levels of fourthand eighth-grade students using different types of questions, including open-ended questions. The same experts as above were consulted regarding the appropriateness of the PISA and TIMMS questions to the objectives and the levels of seventhgrade students. In addition, the opinions of an English teacher were consulted about the appropriateness of the translation from English into Turkish. Based on the opinions received, the questions were determined to be faithful to the original versions. The exam duration was determined to be $30 \mathrm{~min}$. The questions were marked according to the scoring guide published by PISA and TIMMS, which indicates that full answers receive 2 points, partial answers 1 point, and missing answers and answers which do not address the question 0 points. According to this grading, the maximum and minimum scores one can obtain on SPLT are 14 and 0 points, respectively.

LTGT

The original version of this 21-item test was developed by Roadrangka et al. (1982) by selecting highly reliable and valid items from tests (Ankney and Joyce, 1974; Burney, 1974; Lawson's Classroom Test of Formal Operation, 1978; Longeol, 1968 as cited in Korkmaz, 2002) measuring students'various reasoning skills. Reliability and validity analyses indicate that the test was applicable to measuring abstract reasoning skills of students from sixth grade in secondary school to graduate level. Korkmaz (2002) applied the test to seventh-grade students to measure their problem-solving skills and showed that it could be used to measure logical thinking and problem-solving skills of students from the secondary level in Turkey (Korkmaz, 2002). The LTGT consisted of 18 multiple-choice questions that required an answer with justification and three open-ended questions. A correct answer and appropriate justification for each multiple-choice question were given 1 point; otherwise, 0 points were awarded. A correct answer to the open-ended questions was given 1 point, and an incorrect answer was given 0 points. The alpha reliability coefficient was found to be 0.78 . The test was applied to the experimental and control groups at pre-test and post-test. The exam duration was determined to be $40 \mathrm{~min}$.

\section{Data Analysis}

SPSS 18.0 software was used to analyze the data. The groups' grade point averages on the Science and Technology course at the end of sixth grade and the first term of seventh grade were analyzed using the Kruskal-Wallis $\mathrm{H}$ Test to determine their equivalence, and two-way ANOVA for independent samples was used to analyze the data obtained on MCAAT, SPLT, and LTGT. The experimental and control groups were compared according to their scores. Relevant statistical techniques in the SPSS 18.0 software indicated that the MCAAT, SPLT, and LTGT scores display a normal distribution and their variances are homogeneous.

\section{RESULTS}

In this section, the results and their interpretation according to the research questions are presented.

Results and Interpretations of the First Research Question According to Table 3, the mean scores of the experimental and control groups on MCAAT were 6.12 and 3.87, respectively. As Table 4 shows, the experimental group achieved significantly better scores on $\operatorname{MCAAT}\left(F(1.98)=9.245, \rho<0.05, \eta^{2}=0.086\right)$. 
It can thus be said that teaching CR practices were more effective in improving students' academic achievement than teaching according to the curriculum.

Regarding item "a" of the first research question, Table 3 shows that the mean scores of the female and male participants' on MCAAT were 5.72 and 4.12, respectively. Table 4 shows that the female students achieved significantly betters scores $\left(F(1.98)=4.396, \rho<0.05, \eta^{2}=0.043\right)$.

Regarding item "b" of the first research question, the two-way ANOVA results in Table 4 show that the common effect of the method implemented and gender on the students' scores on MCAAT was not significant $\left(F(1.98)=1.555, \rho>0.05, \eta^{2}=\right.$ 0.016). According to this, it can be said that the common effect of the method implemented and gender was not effective in improving students' academic achievement.

\section{Results and Interpretations of the Second Research Question}

Regarding the second research question, Table 5 shows that the mean scores of the experimental and control groups on SPLT were 4.00 and 1.64, respectively. Table 6 shows that the experimental group's students were significantly more successful $\left(F(1.98)=17.947, \rho<0.05, \eta^{2}=0.155\right)$. It can be concluded that teaching $\mathrm{CR}$ practices were more effective in improving students' science performance levels than teaching according to the curriculum.

Regarding item "a" of the second research question, Table 5 shows that the mean scores of the female and male participants

\begin{tabular}{|c|c|c|c|c|c|c|c|c|c|}
\hline \multirow[t]{2}{*}{ Components } & \multicolumn{3}{|c|}{ Female } & \multicolumn{3}{|c|}{ Male } & \multicolumn{3}{|c|}{ Total } \\
\hline & $\mathrm{N}$ & $\overline{\mathrm{x}}$ & $\mathbf{S}$ & $\mathbf{N}$ & $\overline{\mathrm{X}}$ & $\mathbf{S}$ & $\mathrm{N}$ & $\overline{\mathrm{x}}$ & $\mathbf{S}$ \\
\hline Critical Reading & 25 & 6.44 & 4.33 & 24 & 5.79 & 3.71 & 49 & 6.12 & 4.01 \\
\hline Curriculum & 28 & 5.07 & 3.31 & 25 & 2.52 & 4.02 & 53 & 3.87 & 3.85 \\
\hline Total & 53 & 5.72 & 3.85 & 49 & 4.12 & 4.17 & 102 & 4.95 & 4.07 \\
\hline
\end{tabular}

\begin{tabular}{lcccccc}
\hline \multicolumn{7}{l}{ Table 4: Two-way ANOVA results for MCAAT scores } \\
\hline $\begin{array}{l}\text { Source of } \\
\text { variance }\end{array}$ & $\begin{array}{c}\text { Sum of } \\
\text { squares }\end{array}$ & SD & $\begin{array}{c}\text { Mean of } \\
\text { squares }\end{array}$ & $\mathbf{F}$ & $\mathbf{( \rho )}$ & $\boldsymbol{\eta}^{2}$ \\
\hline Group & 136.813 & 1 & 136.813 & 9.245 & 0.003 & 0.086 \\
Gender & 65.055 & 1 & 65.055 & 4.396 & 0.039 & 0.043 \\
Group x Gender & 23.013 & 1 & 23.013 & 1.555 & 0.215 & 0.016 \\
Error & 1450.215 & 98 & 14.798 & & & \\
Total & 4171 & 102 & & & & \\
\hline
\end{tabular}

\begin{tabular}{|c|c|c|c|c|c|c|c|c|c|}
\hline \multirow[t]{2}{*}{ Components } & \multicolumn{3}{|c|}{ Female } & \multicolumn{3}{|c|}{ Male } & \multicolumn{3}{|c|}{ Total } \\
\hline & $N$ & $\bar{x}$ & $S$ & $\mathbf{N}$ & $\bar{x}$ & $S$ & $\mathbf{N}$ & $\overline{\mathbf{x}}$ & $\mathbf{S}$ \\
\hline Critical Reading & 25 & 3.40 & 3.11 & 24 & 4.63 & 3.15 & 49 & 4.00 & 3.16 \\
\hline Curriculum & 28 & 1.50 & 2.94 & 25 & 1.80 & 1.85 & 53 & 1.64 & 2.47 \\
\hline Total & 53 & 2.40 & 3.14 & 49 & 3.18 & 2.91 & 102 & 2.77 & 3.04 \\
\hline
\end{tabular}

on MCAAT were 2.40 and 3.18, respectively. However, this difference was not significant, as shown in Table $6(\mathrm{~F}(1.98)=$ $1.869, \rho>0.05, \eta^{2}=0.019$ ).

Regarding item "b" of the second research question, the two-way ANOVA results in Table 6 show that the common effect of the method implemented and gender on the students' SPLT scores was not significant $(\mathrm{F}(1.98)=0.688$, $\left.\rho>0.05, \eta^{2}=0.007\right)$. According to this, it can be said that the common effect of the method implemented and gender was not effective in improving students' science performance level.

Results and Interpretations of the Third Research Question Regarding the third research question, Table 7 shows that the mean scores of the experimental and control groups on SPLT were 2.37 and 0.91 , respectively. The experimental group's students were significantly more successful, as shown in Table $8\left(F(1.98)=7.888, \rho<0.05, \eta^{2}=0.074\right)$. It can be concluded that teaching CR practices are more effective in improving students' science performance levels than teaching according to the curriculum.

Regarding the item of "a" the third research question, as seen in Table 7, the mean scores of the female and male participants on LTGT were 1.42 and 1.82, respectively. However, this difference was not significant, as Table 8 indicates $(F(1.98)=$ $0.552, \rho>0.05, \eta^{2}=0.006$ ).

Regarding item of " $b$ " the third research question, the two-way ANOVA results presented in Table 8 show that the common

\begin{tabular}{lcccccc}
\hline \multicolumn{7}{l}{ Table 6: Two-way ANOVA results for SPLT scores } \\
\hline $\begin{array}{l}\text { Source of } \\
\text { variance }\end{array}$ & $\begin{array}{c}\text { Sum of } \\
\text { squares }\end{array}$ & SD & $\begin{array}{c}\text { Mean of } \\
\text { squares }\end{array}$ & $\mathbf{F}$ & $\mathbf{( \rho )}$ & $\boldsymbol{\eta}^{2}$ \\
\hline Group & 141.857 & 1 & 141.857 & 17.947 & 0.000 & 0.155 \\
Gender & 14.777 & 1 & 14.777 & 1.869 & 0.175 & 0.019 \\
Group x Gender & 5.437 & 1 & 5.437 & 0.688 & 0.409 & 0.007 \\
Error & 774.625 & 98 & 7.904 & & & \\
Total & 1721.000 & 102 & & & & \\
\hline
\end{tabular}

Table 7: Descriptive statistics of LTGT scores

\begin{tabular}{|c|c|c|c|c|c|c|c|c|c|}
\hline \multirow[t]{2}{*}{ Components } & \multicolumn{3}{|c|}{ Female } & \multicolumn{3}{|c|}{ Male } & \multicolumn{3}{|c|}{ Total } \\
\hline & $\mathbf{N}$ & $\bar{x}$ & S & N & $\overline{\mathbf{X}}$ & S & N & $\bar{X}$ & S \\
\hline Critical reading & 25 & 2.00 & 2.38 & 24 & 2.75 & 3.48 & 49 & 2.37 & 2.96 \\
\hline Curriculum & 28 & 0.89 & 1.87 & 25 & 0.92 & 2.68 & 53 & 0.91 & 2.26 \\
\hline Total & 53 & 1.42 & 2.18 & 49 & 1.82 & 3.20 & 102 & 1.61 & 2.71 \\
\hline
\end{tabular}

\begin{tabular}{lcccccc}
\hline \multicolumn{7}{l}{ Table 8: Two-way ANOVA results for LTGT scores } \\
\hline $\begin{array}{l}\text { Source of } \\
\text { variance }\end{array}$ & $\begin{array}{c}\text { Sum of } \\
\text { squares }\end{array}$ & SD & $\begin{array}{c}\text { Mean of } \\
\text { squares }\end{array}$ & $\mathbf{F}$ & $\mathbf{( \rho )}$ & $\boldsymbol{\eta}^{2}$ \\
\hline Group & 54.815 & 1 & 54.815 & 7.888 & 0.006 & 0.074 \\
Gender & 3.838 & 1 & 3.838 & 0.552 & 0.459 & 0.006 \\
Group x Gender & 3.32 & 1 & 3.32 & 0.478 & 0.491 & 0.005 \\
Error & 681.019 & 98 & 6.949 & & & \\
Total & 1006 & 102 & & & & \\
\hline
\end{tabular}


effect of the method implemented and gender on the students' LTGT scores was not significant $(\mathrm{F}(1.98)=0.478, \rho>0.05$, $\left.\eta^{2}=0.005\right)$. According to this, it can be said that the common effect of the method implemented and gender was not effective in improving students' problem-solving skills.

\section{DISCUSSION, CONCLUSION, AND RECOMMENDATIONS}

This study aimed to investigate the effect of the using of CR practices in science courses on academic achievement, science performance level, and problem-solving skills. In line with the research objectives, three research questions were formulated: RQ1: Do scores on the MCAAT achieved by the experimental group and the control group differ according to the method implemented? RQ1a: Do scores on the MCAAT achieved by the experimental and control groups differ according to gender? RQ1b: Are scores on the MCAAT achieved by the experimental and control groups affected by the common effect of the method implemented and gender? RQ2: Do scores on the SPLT achieved by the experimental and control groups differ according to the method implemented? RQ2a: Do scores on the SPLT achieved by the experimental and control groups differ according to gender? RQ2b: Are scores on the SPLT achieved by the experimental and control groups affected by the common effect of the method implemented and gender? RQ3: Do scores on the LTGT achieved by the experimental and control groups differ according to the method implemented? RQ3a: Do scores on the LTGT achieved by the experimental and control groups differ according to gender? RQ3b: Are scores on the LTGT achieved by the experimental and control groups affected by the common effect of the method implemented and gender? The results show that the experimental group, in which CR practices were used, had higher academic achievement than the control group in which curriculum-appropriate teaching was followed. This indicates that CR practices were effective in improving students' academic achievement levels. This finding is corroborated by the literature. Akın (2014) found that teaching science courses based on CR practices was effective in increasing eighth-grade students' academic achievement. Karabay (2012) showed that education programs incorporating $\mathrm{CR}$ and writing were more effective in raising students' academic achievement. Çam (2006) found significant relationships between visual reading and CR and between reading comprehension and academic achievement in Turkish classes. David (2009) found that groups in which CR practices were used were more academically successful than those in which traditional reading practices were used.

The results also show that female students had better academic achievement than their male counterparts. However, the common effect of the method implemented and gender on academic achievement level was not significant. This result is also corroborated by the literature. Bayat et al. (2014) found that female eighth-grade students performed better in reading comprehension and science achievement tests.
Gündüver (2011) found that female primary school students performed better than male students on the placement test according to various variables. There are also studies which find no significant difference in gender (Ötken, 2012; Turhan et al., 2008).

The experimental group was found to have a significantly higher science performance level than the control. This indicates that $\mathrm{CR}$ practices were more effective in improving students' science performance level, which is in line with other studies' findings. Keskin (2008), Süren (2008), and Selim (2013) found that reading or subscribing to a scientific journal improved students' scientific literacy levels. İlkörücü Göçmençelebi and Özkan (2011) showed that sixth-grade students who read scientific journals and newspapers associated what they learned in science courses with daily life at a higher level. Karademir and Uluçınar (2017) found a positive significant relationship between secondary students' CR skills, science literacy levels, and attitudes toward science.

Furthermore, regarding the science performance level, this study found that the students' science performance level did not differ significantly according to gender, and the common effect of the method implemented and gender did not have a significant effect on their science performance level. The experimental group was also found to have significantly better problem-solving skills at the end of the implementation. This too indicates that $\mathrm{CR}$ practices are more effective in improving students' problem-solving skills. No study was encountered in the literature on the effect of CR practices on problemsolving skills. Studies in the relevant literature mostly focus on the effect of reading comprehension on mathematical problem-solving. Özcan (2016) found a significant relationship between secondary school students' reading comprehension level in mathematics classes and their problem-solving skills in fifth and sixth grade, but not in seventh and eighth grade. Kelly and Mousley (2001) compared the verbal and graphical problem-solving skills of normal and hearing-impaired students and investigated the relationship between hearingimpaired students' reading levels and their performance of verbal and graphic problem-solving. They asserted that reading comprehension achievement is essential in problem-solving processes. Jiban and Deno (2007) underlined the importance of reading skills in solving reading-based mathematical problems. Lamb (2010) compared reading level and mathematics achievement and identified reading comprehension as the most crucial factor in the problem-solving process.

Another result of this study regarding problem-solving skills is that these did not differ according to gender. Nor was the common effect of the method implemented and gender found to have a significant effect on the students' problem-solving skills. These results are in line with the results of similar studies (Basmac1, 1998; Çam, 1996; Gholami et al., 2019; Görmez, 1998; Güven and Akyüz, 2001; Özdemir et al., 2016; Özkütük et al., 2003; Saracaloğlu et al., 2009; Serin, 2001; Syaiful et al., 2019). However, there are some studies 
that indicate that students' problem-solving skill levels differ significantly according to gender (Aroral et al., 2020; Dinçer, 1995; Gunawan et al., 2020; Korkut, 2002). As can be seen, the results of this study are largely corroborated by those of the relevant literature.

Reading habits and reading comprehension are factors closely associated with students' academic achievement in all fields and greatly affect learning performance. Reading is also an essential factor guiding the skill of finding effective solutions to complex problems, which is considered the most high-level skill. CR requires an active communication process that enables interpretations and evaluations of the text being read. In CR, the text prepares a substructure for readings of other texts and the reading of other texts prepares a substructure for the text being read. The CR suggests that the message of the text does not end when the reading period ends. These characteristics of $\mathrm{CR}$ are necessary skills of the knowledge and production age (Akın, 2014). In the spirit of the age, it is possible to produce the different and new by internalizing information and thinking processes. International exams such as PISA, TIMMS, and Progress in International Reading Literacy (PIRL) indicate the development of countries' educational systems by measuring students' reading comprehension, their ability to transfer lessons learned to daily life, and problem-solving skills. Countries must instill students with the habit of reading books and students must develop these skills to the level of analysis, syntheses, and evaluation to be successful in international exams. In addition, rather than questions with a single answer, which measure memorized knowledge, exam systems based on open-ended questions and interpretation should be used to assessing students raised in this way. For this reason, reading should not be considered an activity only for teaching mother tongues; reading practices should be incorporated into science and other courses. CR activities enable individuals to question and judge what is read, to compare with prior knowledge, and reach their conclusion. Therefore, individuals must be raised as active learners and apply knowledge learned to their daily life. It is of critical importance to use such innovative practices, which combine various disciplines, to allow students to excel at reading, which is a basic skill, at all educational levels to raise contemporary and social individuals.

Based on the results of this study, several recommendations can be made. For CR, students must know the subjects they are reading. Especially in the activities created by teachers, it should be in a way to provide students with knowledge and to think. If we consider CR as a thinking and evaluation activity, the importance of gaining students' CR skills is more understood. Teachers should be provided pre- and in-service training to provide them with CR skills. Texts in science textbooks should be prepared in a way that nurtures students' CR practices. Classrooms should provide a democratic atmosphere in which students are comfortable expressing their thoughts. Open-ended questions, which enable students to produce high-level thinking and to make interpretations, should be used more in assessments. Activities should be planned in which students apply CR skills to materials such as books, magazines, newspapers, and websites, which they use to reach information. Further descriptive and experimental studies can be conducted with different grades, courses, and unit levels to investigate $\mathrm{CR}$ and other critical thinking skills.

\section{ACKNOWLEDGMENTS}

This study was part of the second author's Master's thesis.

\section{REFERENCES}

Akın, F. (2014). The Effects of Science Teaching Using the Critical Reading Practice on Learning Products. Zonguldak, Turkey: Master's Thesis, Bülent Ecevit University.

Akın, F., Koray, Ö., \& Tavukçu, K. (2015). How effective is critical reading in the understanding of scientific texts? Procedia Social and Behavioral Sciences, 174, 2444-2451.

Altunsöz, D. (2016). Turkish Course Development Class 4. Investigation of Critical Reading Skills Training Program Students. Bartın, Turkey: Master's Thesis. Bartın University.

Arıcı, A.F. (2008). Reading Education. Turkey: Pegem Akademi.

Aroral, R., Arora, P., \& Chadha, B. (2020). Problem solving, reasoning and conceptual understanding in mathematics among senior secondary school students in relation to gender and cognitive styles. Journal of Information and Computational Science, 10(3), 80-98.

Aşılloğlu, B. (2008). The importance of critical reading for cognitive learning and the ways to improve it. Dicle University Journal of Ziya Gökalp Faculty of Education, 10, 1-11.

Basmac1, S.K. (1998). Examining the Perception of Problem Solving Skills of University Students' in Terms of Some Variables. Malatya, Turkey: Unpublished Master's Thesis, Inönü University.

Bayat, N., Şekercioğlu, G., \& Bakır, S. (2014). The relationship between reading comprehension and success in science. Education and Science, $39(176), 457-466$.

Brown, A. (1997). Transforming schools into communities of thinking and learning about serious matters. American Psychologist, 52, 399-413.

Browne, M.N., \& Keeley, S.M. (2007). Asking the Right Questions: A Guide to Critical Thinking. Available from: https://www.bookspdf4free.com/ wp-content/uploads/2019/12/asking-the-right-questions-a-guide-tocritical-thi.pdf.

Çam, B. (2006). The Relationship Between Visual Reading Level and Reading Understanding, Critical Reading and Turkish Lesson Academic Success of Elemantary School Students. Eskişehir, Turkey: Master's Thesis, Eskişehir Osmangazi University.

Çam, S. (1996). The Effect of Communication Skills Training Programme with Teacher Candidates, on Ego States and Perception of Problem Solving Skill. Ankara, Turkey: Unpublished Doctoral Thesi, Ankara University.

Çepni, S. (2005). Introduction to Research and Project Studies. $2^{\text {nd }}$ ed. India: Üçyol Cultural Center.

Cottrell, S. (2011). Critical Thinking Skills: Developing Effective Analysis and Argument. United Kingdom: Palgrave.

Dam, G.T.M., \& Volman, M.L.L. (2004). Critical thinking as a citizenship competence: Teaching strategies. Learning and Instruction, 14(4), 359-379.

David, D.F. (2009). Critical reading an evaluation of a teaching approach. In: $39^{\text {th }}$ IEEE in Frontiers in Education Conference. San Antonio: ABD.

Dincer, F.C. (1995). The Examination of the Effect of Problem Solving Training on the Arquisition of Interpersonal Problem Solving Skills by Five Year Old Children Attending a Kinder Garten. Ankara, Turkey: Unpublished Doctoral Thesis, Hacettepe University.

Emiroğlu, H. (2014). Effect of Critical Reading Teaching on Critical Reading Skill. Düzce, Turkey: Unpublished Master's Thesis, Düzce University.

Ennis, R.H. (1985). Critical thinking and the curriculum. National Forum. Phi Kappa Phi Journal, 65(1), 28-31.

Flynn, L.L. (1989). Developing critical reading skills through cooperative 
problem solving. The Reading Teacher, 42(9), 664-668.

Gholami, H., Yunus, A.S.M., Ayub, A.F.M., \& Kamarudind, N. (2019). The impact of lesson study on achievement in mathematical problem solving and higher order thinking skills (HOTS) among foundation level students. International Journal of Innovation, Creativity and Change, 10(2), 289-313.

Görmez, İ. (1998). A Case Study on Problem Solving and Research in Student Teacher Training Before Employment-a Statistical Approach. Sivas, Turkey: Unpublished Master's Thesis, Cumhuriyet University.

Gunawan, G., Mashami, R.A., \& Herayanti, L. (2020). Gender description on problem-solving skills in chemistry learning using interactive multimedia. Journal for the Education of Gifted Young Scientists, 8(1), 571-589.

Güven, A., \& Akyüz, M.Y. (2001). Perception of teacher candidates' communication and problem solving ability. Ege Journal of Education, 1, 13-22.

Halpern, D.F. (1998). Teaching critical thinking for transfer across domains: Disposition, skills, structure training, and metacognitive monitoring. American Psychologist, 53(4), 449-455.

İlkörücü Göçmençelebi, Ş., \& Özkan, M. (2011). Does the use of technology and reading scientific publications affect the ability to relate science lesson knowledge to daily life a comparative study of turkish primary school students. Journal of Uludag University Faculty of Education, 24(1), 287-296.

Jiban, C.L., \& Deno, S.L. (2007). Using math and reading curriculumbased measurements to predict state mathematics test performance: Are simple oneminute measures technically adequate? Assessment for Effective Intervention, 32, 78-89.

Karabay, A. (2012). The Effect of Critical Reading-writing Training on the Academic Achievement and the Critical Reading-writing Levels of Turkish Language Prospective Teacher. Adana, Turkey: Unpublished Doctoral Thesis, Çukurova University.

Karabay, A. (2015). Effect of critical reading education on metacognitive reading strategies and media literacy. Journal of Theory and Practice in Education, 11(4), 1167-1184.

Karabay, A., Kuşdemir Kayıran, B., \& Işık, D. (2015). The investigation of pre-service teachers' perceptions about critical reading self-efficacy. Eurasian Journal of Educational Research, 59, 227-246.

Karademir, E., \& Uluçınar, U. (2017). Examining the relationship between middle school students' critical reading skills, science literacy skills and attitudes: A structural equation modeling. Journal of Education in Science, Environment and Health, 3(1), 29-39.

Karasar, N. (2003). Scientific Research Method. $12^{\text {th }}$ ed. Maharashtra: Nobel Publishing.

Kelly, R.R., \& Mousley, K. (2001). Solving word problems: More than reading issues for deaf students. American Annals of the Deaf, 146(3), 251-262.

Keskin, H. (2008). Second Step of Primary Students? Level of Scientific Literacy Related to Science and Technology Course. Eskişehir, Turkey: Unpublished Master's Thesis, Osmangazi University.

Kien, L.T., \& Huan, N.B. (2017). Teacher beliefs about critical reading strategies in english as a foreign language classes in Mekong Delta institutions, Vietnam. European Journal of English Language Teaching, 2(4), 39-57.

Korkmaz, H. (2002). The Effects of Project Based Learning on Creative Thinking Ability, Problem Solving Ability and Level of Academic Risk Taking in Science Education. Ankara, Turkey: Unpublished Doctoral Thesis, Hacettepe University.

Korkut, F. (2002). Problem solving skills of high school students. Hacettepe University Journal of Education, 22, 177-184.

Krug, K.A. (2010). Critical Literacy in the Face of a Mandated Curriculum: Can Children Read Beyond the Text? United States: George Washington University.

Lamb, J. (2010). Reading grade levels and mathematics assessment: An analysis of Texas mathematics assessment 1tems and their reading difficulty. The Mathematics Educator, 20(1), 22-34.

Literacy Gains. (2009). Connecting Practice and Research: Critical Literacy Guide. Available from: http://www.edugains.ca/resourcesLIT/ CoreResources/Critical_Literacy_Guide.pdf.

Maker, J., \& Lenier, M. (1996). Academic Reading with Active Critical
Thinking. United Kingdom: Wadsworth Publishing Company.

Maltepe, S. (2016). An analysis of the critical reading levels of pre-service Turkish and literature teachers. Eurasian Journal of Educational Research, 63, 169-184.

McClune, B., \& Jarman, R. (2010). Critical reading of science based news reports: Establishing a knowledge. Skills and attitudes framework. International Journal of Science Education, 32(6), 727-752.

McLaughlin, M., \& De Voogd, G. (2004a). Critical literacy as comprehension: Expanding reader response. Journal of Adolescent and Adult Literacy, 48(1), 52-62.

McLaughlin, M., \& De Voogd, G. (2004b). Critical Literacy: Enhancing Students' Comprehension of Text. Tamil Nadu: Scholastic Publisher.

Ministry of National Education (MoNE). (2013). Science Curriculum, 3rd, 4th, 5th, 6th, 7th, and 8th Grades. United States: Board of Education and Discipline.

Molden, K. (2007). Critical literacy, the right answer for the reading classroom: Strategies to move beyond comprehension for reading improvement. Reading Improvement, 44(1), 50-56.

Norris, S.P. (1985). Synthesis of research on critical thinking. Educational Leadership, 42(8), 40-45.

Ötken, Ş. (2012). Determining the Variables of Predictors on the Success of $7^{\text {th }}$ Grade Students in Level Determination Exam. Ankara, Turkey: Unpublished Master's Thesis, Hacettepe University.

Özcan, Y. (2016). The Relati on Between Problem Solving in Math and ReadiNg ComprehensiOn Skill. Elazığ, Turkey: Unpublished Master's Thesis, Firat University.

Özdemir, E. (2007). Critical Reading. $7^{\text {th }}$ ed. Turkey: Bilgi Publishing House.

Özdemir, F., Duran, M., \& Kaplan, A. (2016). İnvestigation of middle school students' self-efficacy perceptions of visual mathematics literacy and perceptions of problem-solving skill. Journal of Theoretical Educational Science, 9(4), 532-554.

Özkütük, N., Silkü, H.A., Orgun, F., \& Yalçınkaya, M. (2003). The problemsolving skills of teacher candidates. Ege Journal of Education, 2, 1-9.

Paul, R. (1992). Critical thinking: What, why, and how. New Directions for Community Colleges, 77, 3-24.

Paul, R., \& Elder, L. (2008). How to Read a Paragraph. CA: The Foundation of Critical Thinking. Available from: https://www.criticalthinking.org/ store/get_file.php?inventories_id=157\&inventories_fi.

Paul, R., Binker, A., Jensen, K., \& Kreklau, H. (1990). Critical Thinking Handbook: A Guide for Remodeling Lesson Plans in Language Arts, Social Studies and Science. United States: Foundation for Critical Thinking.

Pithers, R.T., \& Soden, R. (2000). Critical thinking in education: A review. Educational Research, 42(3), 237-249.

Roadrangka, V., Yeany, R.H., \& Padilla, M.J. (1982). GALT, Group Test of Logical Thinking. Georgia: University of Georgia.

Saracaloğlu, A.S., Yenice, N., \& Karasakaloğlu, N. (2009). The relationship between communication and problem solving skills and reading interest and habits of candidate teachers'. Journal ossssaaaf Yüzüncü Yll University Faculty of Education, 6(2), 167-185.

Selim, G. (2013). The Investigation of the Effects of the SciEnce MagaziNes on the Scientific literacy and the Attitudes Towards the Science and Technology Lesson of the Seventh Grade Students. İstanbul, Turkey: Unpublished Master's Thesis, Marmara University.

Serin, O. (2001). Prospective Teachers Perceptions of Their Own Problem Sollving Skills, their Attitudes Towards Science and Computer and the Relationship Between their Attitudes and their Achievement. İzmir, Turkey: Unpublished Doctoral Thesis, Dokuz Eylül University.

Sönmez, V., \& Alacapınar, F.G. (2014). Sampled Scientific Research Methods. $3^{\text {rd }}$ ed. Ankara: Anı Publishing.

Süren, T. (2008). Scientific Literacy Levels of Elementary School Students at Primary Schools. Afyon, Turkey: Unpublished Master's Thesis, Kocatepe University.

Syaiful, M., Huda, N., Mukminin, A., \& Habibi, A. (2019). Communication skills and mathematical problem solving ability among junior high schools students through problem-based learning. International Journal of Scientific and Technology Research, 8(11), 1048-1060.

Tsai, P.Y., Chen, S., Chang, H.P., \& Chang, W.H. (2013). Effects of 
prompting critical reading of science news on seventh graders' cognitive achievement. International Journal of Environmental and Science Education, 8(1), 85-107.

Turhan, F., Aydoğdu, M., Şensoy, Ö., \& Yıldırım, H.İ. (2008). Analysis of the relationship among cognitive growth, science achievement, attitudes towards science and gender of the eighth. Kastamonu Education Journal, 16(2), 439-450.
Ünal, E. (2006). The Relation between Primary School Students Critical Reading Skills and Ability of Reading Understanding and Their Attitudes Towards Reading. Eskișehir, Turkey: Unpublished Master's Thesis, Osmangazi University.

$\mathrm{Yu}$, J. (2015). Analysis of critical reading strategies and its effect on college English reading. Theory and Practice in Language Studies, $5(1), 134-138$. 